\title{
Litter Decomposition Rate of Karst Ecosystem at Gunung Cibodas, Ciampea Bogor Indonesia
}

\author{
Sethyo Vieni Sari ${ }^{1 *}$, Ibnul Qayim ${ }^{2}$, Iwan Hilwan ${ }^{3}$
}

\author{
${ }^{1}$ Study Program of Plant Biology, Graduate School of Bogor Agricultural University, Bogor, Indonesia \\ ${ }^{2}$ Department of Biology, Faculty of Mathematics and Natural Sciences, Bogor Agricultural University, Bogor, Indonesia \\ ${ }^{3}$ Department of Silviculture, Faculty of Forestry, Bogor Agricultural University, Bogor, Indonesia
}

\begin{abstract}
The study aims to know the productivity of litter and litter decomposition rate in karst ecosystem. This study was conducted on three altitude of 200 meter above sea level (masl), 250 masl and 300 masl in karst ecosystem at Gunung Cibodas, Ciampea, Bogor. Litter productivity measurement performed using litter-trap method and litter-bag method was used to know the rate of decomposition. Litter productivity measurement results showed that the highest total of litter productivity measurement results was on altitude of 200 masl (90.452 tons/ha/year) and the lowest was on altitude of $300 \mathrm{mas}$ (25.440 tons/ha/year). The litter productivity of leaves (81.425 ton/ha/year) showed the highest result than twigs (16.839 ton/ha/year), as well as flowers and fruits (27.839 ton/ha/year). The rate of decomposition was influenced by rainfall. The decomposition rate and the decrease of litter dry weight on altitude of 250 masl was faster than on the altitude of 200 masl and 300 masl. The dry weight was positively correlated to the rate of decomposition. The lower of dry weight would affect the rate of decomposition become slower. The average of litter $\mathrm{C} / \mathrm{N}$ ratio were ranged from $28.024 \%-28.716 \%$ and categorized as moderate $(>25)$. The finding indicate that the rate of decomposition in karst ecosystem at Gunung Cibodas was slow and based on C/N ratio of litter showed the mineralization process was also slow.
\end{abstract}

Keywords: C/N ratio, decomposition, Gunung Cibodas, karst ecosystem, litter

\section{INTRODUCTION}

Karst ecosystem is a limestone consisting ecosystem which contains rainwater soluble calcium carbonate or calcite. Karst ecosystem has a unique and high potential resources that should be utilized in a sustainable manner for surrounding community, such as forest. Forests in karst region need to get protection because it is a resource that has a cultural, ecological and high economic value.

Litter is an important component in forest ecosystem. The amount and concentration of nutrients that was contained by litter is an energy sources of the nutrient cycle [1]. Litter transferred the nutrients and energy of vegetation into soil that is a major process in biogeochemical cycles [2]. Litter decomposition is the main path to supply the organic and inorganic materials in the process of recycling the soil nutrients and return nutrients to ecosystem. Kang et al. (1999) [3] also

${ }^{*}$ Corresponding author:

Sethyo Vieni Sari

Study Program of Plant Biology, Graduate School of Bogor

Agricultural University, Bogor 16680, Indonesia

E-mail: phieyhenne@gmail.com stated that the litter can help to supply the needs of nitrogen $(\mathrm{N})$ element and it can reduce $\mathrm{N}$ fertilizer on the agricultural land.

Types of ecosystem, quantity, and quality of litter will affect the decomposition process [4]. The quality of litter which can be affected the decomposition process i.e. size of litter, $\mathrm{C} / \mathrm{N}$ ratio, and chemical composition [5]. The research on litter decomposition rate of Acacia crassicarpa showed that the $\mathrm{C} / \mathrm{N}$ ratio can be used as an indicator of litter decomposition because decomposition of organic materials will reduce the $\mathrm{C} / \mathrm{N}$ ratio of litter [6]. It indicated that the content of organic $\mathrm{C}$ in litter will be lower because it will be used by microbes as an energy sources. While, the $\mathrm{N}$ content in the materials will increase. It means that the mineralization process was continued. The decomposition is important in forest ecosystem because it can reduce the accumulation of litter on the soil and maintain the soil

\section{How to cite:}

Sari SV, Qayim I, Hilwan I (2016) Litter Decomposition rate of karst ecosystem at Gunung Cibodas, Ciampea Bogor Indonesia. J. Trop. Life. Science 6 (2): 107 - 112. 
fertility that was always decreased by the absorption of nutrients by plants [7].

It is important to study in detail about the determination of relationship between soil and vegetation in an ecosystem, such as composting of organic materials. The previous study in karst region at Gunung Cibodas only about ecology of vegetation and ethnobotany [8], the species composition and structure of vegetation [9], the diversity of flora [10], and the dynamics of plant chlorophyll content and LAI of Prunus avium [11]. The rate of litter decomposition in karst ecosystem at Gunung Cibodas has been unexplored. The study of litter decomposition in the karst region is very important because litter is the source of nutrients to the ecosystem. This study aims to determine the productivity of litter and the rate of litter decomposition that occurs in karst ecosystem at Gunung Cibodas.

\section{MATERIALS AND METHODS Productivity of litter}

Productivity measurement of litter used litter-trap method Brown 1984 [12]. The total of 15 litter-traps were placed on each altitude in meter above sea level (masl) i.e. 200 masl, 250 masl and 300 masl with a size of $1 \mathrm{~m} \times 1 \mathrm{~m}$ under trees and $50 \mathrm{~cm}$ height above the ground. Litter was transported to the laboratory and dried at $70{ }^{\circ} \mathrm{C}$ until its weight was constant.

\section{Decomposition of litter}

The measurement of litter decomposition used litttter-bag method. Samples were collected using a littertrap (litter container tool method) in order not touched the ground Brown 1984 [12]. Litter was deposited at the laboratory and dried at $70{ }^{\circ} \mathrm{C}$ until its weight was constant [13]. A total of $20 \mathrm{~g}$ dried litter was put into a litter-bag with a size of $30 \mathrm{~cm} \times 20 \mathrm{~cm}$. Every week three litter-bags was taken from every altitude and brought to the laboratory, then it was dried at $70{ }^{\circ} \mathrm{C}$ and analysis of carbon (C) and nitrogen $(\mathrm{N})$ content of dried litter was done in Soil Laboratory at Center of Agricultural Resources, Soil Research Institute, Bogor.

\section{Data analysis}

Weight reduction was obtained by formula:

$$
W=\frac{W 0-W t}{W 0} \times 100 \%
$$

$$
\begin{array}{ll}
\text { Wo } & \text { : initial dry weight of litter } \\
\text { Wt } & \text { : final dry weight of litter }(\mathrm{g}) \text { per time period } \mathrm{t} \\
\mathrm{W} & \text { : weight loss }
\end{array}
$$

Litter decomposition rate was calculated using the formula:

$$
R=\frac{W 0-W t}{T}
$$

$$
\begin{array}{ll}
\mathrm{R} & \text { : the rate of decomposition ( } \mathrm{g} / \text { week }) \\
\mathrm{T} & \text { : time of observation (week) } \\
\mathrm{W} 0 & \text { : initial dry weight of litter } \\
\mathrm{Wt} & \text { : final dry weight of litter }(\mathrm{g}) \text { per time period } \mathrm{t}
\end{array}
$$

Estimation of constant value of litter decomposition rate was obtained by using the formula Ashton et al. 1999 [13]:

$$
\begin{gathered}
\mathrm{Wt}=\mathrm{W} 0 . \mathrm{e}^{-\mathrm{kt}} \\
\ln (\mathrm{Wt} / \mathrm{W} 0)=-\mathrm{kt}
\end{gathered}
$$

$$
\begin{array}{ll}
\text { Wt } & \text { : weight of dried litter after observation time to } \mathrm{t}(\mathrm{g}) \\
\mathrm{W} 0 & : \text { initial dry weight of litter }(\mathrm{g}) \\
\mathrm{e} & \text { : total natural logarithm }(2.72) \\
\mathrm{k} & \text { : constant of litter decomposition rate } \\
\mathrm{t} & \text { : time of observation (week) }
\end{array}
$$

\section{RESULTS AND DISCUSSION \\ Litter productivity}

Each altitude had a high productivity of leaves litter then followed by twigs, flowers and fruits. The leaves litter was the largest category followed by twigs, flowers and fruits. The largest category of leaves litter was caused by the shape of the leaves was wide and thin so it was easily fall by wind and rain or due to the physiological properties of leaves [14]. The highest amount of leaves litter productivity was affected by two major factor i.e. the age of leaves itself and mechanical factors. Leaves will naturally fall when it reached a certain age. It could be affected by wind speed and rainfall. The litttter productivity fluctuated with rainfall, the high inten sity of rainfall would affect the litter productivity become higher [15].

An altitude of 200 masl had the highest productivity of litter compared with an altitude of 250 masl and 300 masl. One of the factors that influenced it i.e. the density of trees. The density on an altitude of 200 masl was $25.600 \mathrm{ind} /$ ha higher than on an altitude of 250 masl (11.000 ind/ha), and $300 \mathrm{masl}$ (11520 ind/ha). The research on production and litter decomposition rate of oil plantation and forest at Serolangun, Jambi also stated that density of trees was one of factor that influenced the litter productivity [16]. Litter productivity decreased due to lower of tree density. The productivity of leaves litter on an altitude of 200 masl reached 


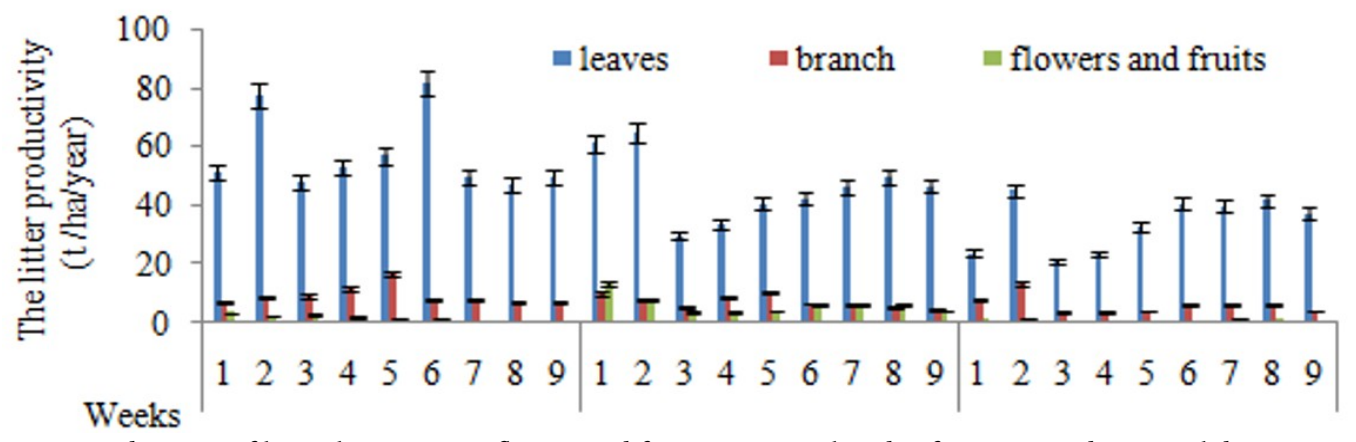

Figure 1. Productivity of litter (leaves, twigs, flowers and fruits) at every altitude of 200, 250 and 300 masl during 9 weeks

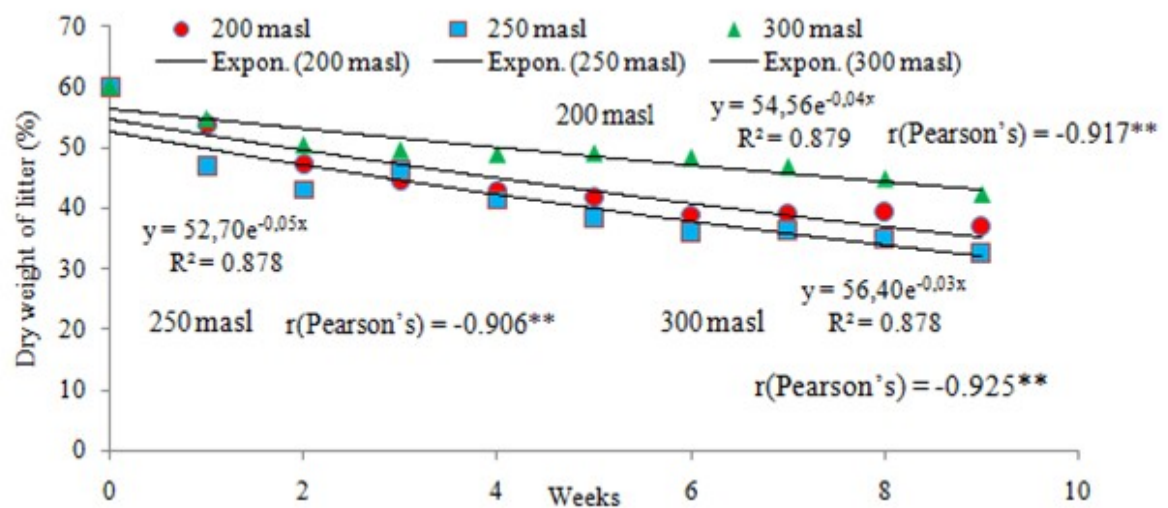

Figure 2. Exponential curve of litter dry weight (\%) at every altitude of of 200, 250 and 300 masl during 9 weeks

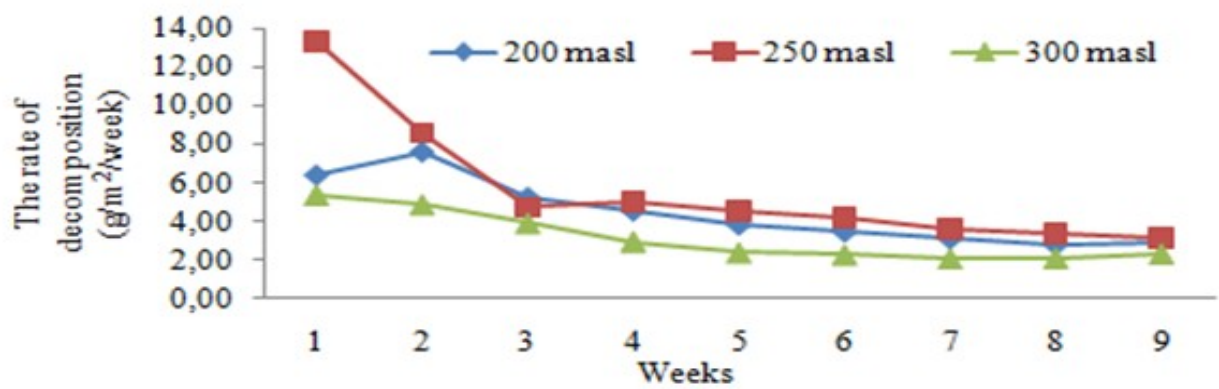

Figure 3. Rate of decomposition at any height of 200, 250 and 300 meters above sea level for 9 weeks

81.425 tonnes/ha/year. Productivity of twigs litter on an altitude of 200 masl reached 16.839 tonnes/ha/year. Productivity of flowers and fruits litter on an altitude of 250 masl reached 13.363 tonnes/ha/year (Figure 1).

Productivity of litter is important to be explored in relation with the transport of energy and nutrients in forest ecosystem. The supply of nutrients derived from the leaves, twigs, fruits, and flowers by release some minerals through the decomposition process [17]. The transfer of organic material in vegetation through a decomposition process was determined by the amount and quality of the litter [18]. The fast-decomposed of litter play an important role to improve nutrient cycle in soil.

\section{Rate of decomposition}

The decrease of litter dry weight was faster on an altitude of 250 masl than on an altitude of 200 masl and 300 masl (Figure 2). Litter dry weight was positively correlated with the rate of decomposition. The correlation between the two variables were very strong and significantly different/significant. The lower of dry weight would affect the rate of decomposition become slower. The dry weight was a parameter to see the in- 
crease of biomass, without being affected by the fluctuations in water levels which can affect the total weight. The result of this research showed that the dry weight of litter declined every weeks until 9th week of observation. The changes of litter weight per unit time was caused by the decomposition process, soil microorganisms utilized the carbon compounds in litter as energy source and released as $\mathrm{CO} 2$ [6]. Litter decomposition rate was higher in the early stages of decomposition process at the altitude of 250 masl. The decrease of litttter weight was common very fast in the first weeks of observation [19]. The process of decomposition was influenced by time. The longer period of decomposition, the higher percentage of loss of litter weight. The rate constant of decomposition can be an indicator of the nutrients return in terrestrial ecosystems [20].

The estimation of the decomposition rate constant value on each of altitudes were 0.044 (200 masl), 0.049 (250 masl), and 0.032 (300 masl) (Table 1$)$. The value of constant coefficient was classified as high $(\mathrm{k}>2)$, moderate $(\mathrm{k}=1-2)$, and low $(\mathrm{k}<1)$ [19]. The constant value of decomposition rate indicated that the rate of decomposition in karst ecosystem at Gunung Cibodas, Ciampea, Bogor was low. The coefficient constant value of decomposition rate in the karst ecosystem at Gunung Cibodas was lower than the African tropical forests which had a constant value i.e. 4 [21]. The rate of litter decomposition on an altitude of 250 masl was faster than on an altitude of 200 masl and 300 masl

Table 1. Estimation of litter decomposition rate constant value any height in the Karst ecosystem

\begin{tabular}{cc}
\hline Elevation & Constants Coefficient \\
\hline 200 masl & 0.044 \\
250 masl & 0.049 \\
300 masl & 0.032 \\
\hline
\end{tabular}

Table 2. Average content of $\mathrm{C}, \mathrm{N}$, and $\mathrm{C} / \mathrm{N}$ ratio in the litter and soil in Karst ecosystem

\begin{tabular}{ccccc}
\hline \multirow{2}{*}{ Parameter $\begin{array}{c}\text { Elevation } \\
\text { (masl) }\end{array}$} & \multicolumn{4}{c}{ contents (\%) } \\
\cline { 3 - 5 } & 200 & $39.25 \pm 5.97$ & $1.40 \pm 0.30$ & $28.72 \pm 5.45$ \\
\multirow{4}{*}{ Litter } & 250 & $38.83 \pm 5.79$ & $1.39 \pm 0.24$ & $28.16 \pm 4.07$ \\
& 300 & $38.76 \pm 5.24$ & $1.39 \pm 0.25$ & $28.02 \pm 3.41$ \\
\hline \multirow{3}{*}{ Soil } & 200 & $3.96 \pm 0.78$ & $0.43 \pm 0.07$ & $9.31 \pm 1.79$ \\
& 250 & $3.19 \pm 0.81$ & $0.36 \pm 0.08$ & $8.95 \pm 1.24$ \\
& 300 & $2.72 \pm 0.69$ & $0.29 \pm 0.06$ & $9.42 \pm 1.74$ \\
\hline
\end{tabular}

(Figure 3). This could be influenced by the dry weight of litter was fast-reduced on an altitude of 250 masl and it showed that the rate of litter decomposition was in line with the reduction of dry weight that were also fast on an altitude of 250 masl.

The $\mathrm{C} / \mathrm{N}$ ratio $<25$ was categorised as high quality of litter. The content of $\mathrm{C} / \mathrm{N}$ ratio in litter affected the decomposition rate. $\mathrm{C} / \mathrm{N}$ ratio is an excellent indicator to determine the rate of decomposition [22]. The litter with $\mathrm{C} / \mathrm{N}$ ratio of $<20$ is categorized as a high-quality litter, the litter with $\mathrm{C} / \mathrm{N}$ ratio of $20-40$ is categorized as moderate quality, and the litter with $\mathrm{C} / \mathrm{N}$ ratio $>40$ is categorized as low quality. The advanced decomposition of organic matter was characterized by the low of $\mathrm{C} / \mathrm{N}$ ratio, while the high contents of $\mathrm{C} / \mathrm{N}$ ratio indicated that the decomposition process was not advanced or it just starting.

The average of litter $\mathrm{C} / \mathrm{N}$ ratio on every altitudes were 28.716 (200 masl), 28.162 (250 masl), and 28.024 (300 masl) (Table 2). The $\mathrm{C} / \mathrm{N}$ ratio of litter in karst ecosystem at Gunung Cibodas were $>25$ that indicated that the process of decomposition were categorized as moderate. The research on the influence and dosage of litter on soil nitrification was also found that the ratio of $\mathrm{C} / \mathrm{N}>25$ and categorized as moderate. The result indicated that the element was slowly available to fulfill the nutrients of plants [23].

The litter quality can affected the formation of soil organic matter [24]. The reduced value of $\mathrm{C} / \mathrm{N}$ indicated that the content of organic carbon in litter had been used as energy source by microorganisms, whereas the content of nitrogen will increase which means the mineralization process run continuously. The $\mathrm{C} / \mathrm{N}$ ratio is a good indicator for quality of organic material of plants, as a source of nutrients and energy for soil macrofauna. The decomposition process was slowed down, as the organic materials was decomposed that caused the decrease of $\mathrm{C} / \mathrm{N}$ ratio in litter. The lower of $\mathrm{C} / \mathrm{N}$ ratio value would affect the quality of litttter become better [25].

The average of soil $\mathrm{C} / \mathrm{N}$ ratio on every altitudes were 9.314 (200 masl), 8.947 (250 masl), and 9.417 (300 masl) (Table 2). The $\mathrm{C} / \mathrm{N}$ ratio was used as an ease index of decomposed organic materials and as an indicator of biological activity. Higher the ratio in litttter, the lower quality of litter itself, so it is difficult to decompose. The $\mathrm{C} / \mathrm{N}$ ratio $<25$ indicates that nitrogen was mineralized and it caused the death of micro-organisms, so the decomposition into other simple elements. The $\mathrm{C} / \mathrm{N}$ ratio indicated that the mineralization-immobilization of nitrogen by decomposers of or- 
ganic material. The content of $\mathrm{C} / \mathrm{N}$ in the litter used as nutrients for microorganisms that play a role in degrading organic matter into inorganic compound substrate. The $\mathrm{C} / \mathrm{N}$ ratio of soil is also influenced by rainfall, temperature, decomposers, and $\mathrm{C} / \mathrm{N}$ ratio of plants above [26].

\section{CONCLUSION}

The total of litter productivity on an altitude of 200 masl was higher than at altitude of 250 masl and 300 masl. One of factor that affected the litter productivity was the density of plant. The decomposition rate in karst ecosystem at Gunung Cibodas was slow and based on $\mathrm{C} / \mathrm{N}$ ratio of litter was classified as moderate that indicated the slow of mineralization process.

\section{ACKNOWLEDGMENT}

This research was supported by an academic scholarship, the Directorate of Higher Education, Ministry of Research and Technology, Republic of Indonesia awarded to Sethyo Vieni Sari.

\section{REFERENCES}

1. Vitousek PM (1984) Litterfall, nutrient cycling, and nutrient limitation in tropical forests. J Ecol 65:285-298.

2. Liu C, Westman CJ, Berg B et al (2004) Variation in litterfall-climate relationships between coniferous and broadleaf forests in Eurasia. Global Ecol and Biogeogr 13:105-114.

3. Kang BT, Caveness FE, Tian G et al (1999) Long term alley cropping with four hedgrew species on an Alfisol in southwestern Nigeria-effect on crop performance, soil chemical properties and nematode population. Nutr Cycl Agrosyst 54: 145-155.

4. Haettenschwiler S, Coq S, Barantal S et al (2011) Leaf traits and decomposition in tropical rainforests: revisiting some commonly held views and towards a new hypothesis. New Phytol 189: 950-965.

5. Taylor BR, Parkinson D, Parsons W (1989) Nitrogen and lignin content as predictors of litter decay rates: a microsom test. Ecology 70: 97-104.

6. Aprianis Y (2011) Litter production and decomposition rate Acacia crassicarpa A. Cunn. PT. Arara Abadi. J Tekno Hutan Tanaman 4 (1): 41-47.

7. Soegiman (1982) Ilmu Tanah. Jakarta, Bratara Karya Aksara.

8. Marwiyati (2012) Vegetation ecology and ethnobotany karst area of Gunung Cibodas, Ciampea, Bogor. Undergraduate Thesis. Bogor Agricultural Institute, Faculty of Mathematics and Natural Sciences.

9. Peniwidiyanti (2014) The species composition and structure of vegetation in karst region of Gunung Cibodas District of Bogor Regency Ciampea. Undergraduate Thesis. Bogor
Agricultural Institute, Faculty of forestry.

10. Sartika M (2007) Species diversity and structure of vegetation in karst region of Gunung Cibodas District of Bogor Regency Ciampea. Undergraduate thesis. Bogor Agricultural Institute, Faculty of forestry.

11. Hafiz ML (2014) Dynamics of chlorophyll content and LAI Prunus avium in karst ecosystem Ciampea Bogor. Undergraduate thesis. Bogor Agricultural Institute, Faculty of Mathematics and Natural Sciences.

12. Brown SM (1984) Mangrove Litter Production and Dynamics in Snedaker CS and Snedaker GJ. 1984. The Mangrove Ecosystem: Research Metods. On behalf of The Unesco/SCOR, Working Group 60 On Mangrove Ecology Page 231-238.

13. Ashton EC, Hogarth PJ, Ormond R (1999) Breakdown of mangrove leaf litter in a managed mangrove forest in Peninsular Malaysia. Hydrobiologia 413: 77-88.

14. Nilamsari D (2000) Productivity, destruction, and nutrient content of litter in stands of pine (Pinus), Puspa (Schima wallichii) and Agathis (Agathis loranthifolia) in the watershed forest Cipereu education Gunung Walat, Sukabumi. Undergraduate thesis. Bogor Agricultural Institute, Faculty of Forestry.

15. Triadiati, Tjitrosemito S, Guhardja E et al (2011) Litterfall production and leaf-litter decomposition at natural forest and cacao agroforestry in Central Sulawesi, Indonesia. Asian J Biol Science 4:221-234.

16. Violita (2015) Production and decomposition rate of litter on oil palm (Elaeis guineensis) and natural forest in Jambi province Sarolangun district. Dissertation. Bogor Agricultural Institute, Faculty of Mathematics and Natural Sciences.

17. Darmanto D (2003) Productivity and litter decomposition prediction model on the stand Agathis (Agathis lorantifolia Salisb.), Puspa (Schima wallichii D.C. Korth.), and pine (Pinus merkusii Jungh et de Vriese.) In Sub Das Cipeureu educational forest Gunung Walat, Sukabumi. Undergraduate thesis. Bogor Agricultural Institute, Faculty of Forestry.

18. Moraes, Sérgio AL (1999) Studies on polyphenols and lignin of Astroniumurundeuva wood. J. Braz. Chem. Soc. Brazil 6(10): 447-452.

19. Torreta NK, Takeda H (1999) Carbon and nitrogen dynamics of decomposing leaf litter in tropical hill evergreen forest. European Journal of Soil Biology. 37:157-160.

20. Berg B, McClaugherty C (2008) Plant litter: Decomposition humus formation, carbon sequestration. Ed-2. Germany, Springer.

21. Olson JS (1963) Energy storage and the balance of producers and decomposers in ecological systems. Ecology. 44: 322331.

22. BassiriRad H (2005) Nutrient acquisition by plants. Heidelberg, Springer-Verlag Berlin Heidelberg. 
23. Purwanto, Hartati S, Istiqomah S (2014) Influence the quality and dosage of litter on soil nitrification potential and yield of sweet corn. J Ilmu Tanah dan Agroklimatologi. Surakarta: Sains Tanah. 11(1).

24. Budge K, Leifeld J, Hiltbrunner E et al (2010) Litter quality and $\mathrm{pH}$ are strong drivers of carbon turnover and distribution in Alpine Grassland soils. Biogeosciences Discuss. 7:
6207-6242.

25. Setiawan Y, Sugiyarto, Wiryanto (2003) Relationship between the population and mesofauna soil macrofauna containing $\mathrm{C}, \mathrm{N}$, and polyphenols, as well as $\mathrm{C} / \mathrm{N}$ ratio, and polyphenols/ $\mathrm{N}$ of organic materials plant. BioSmart. 5:134137.

26. Sutanto R (2005) Dasar-dasar ilmu tanah. Jakarta, Kanisius. 